\title{
PENGARUH BAURAN PEMASARAN JASA TERHADAP KEPUASAN KONSUMEN MENGGUNAKAN JASA PENGIRIMAN PT JNE
}

\author{
Andi Randhy \\ Syamsul Bachri \\ Program Studi Manajemen S1, Fakultas Ekonomi, Universitas Tadulako \\ Email: randhypettalolo@gmail.com; syamsulbachri@gmail.com
}

\begin{abstract}
This study aims to determine the Effect of Service Marketing Mix Against Consumer Decisions Using Freight Forwarding Services at PT Jalur Nugraha Ekakurir (JNE) Donggala Branch. This type of research is descriptive causal. The population of this study is consumers who use PT JNE's freight forwarding services. The sampling technique in this study used accidental sampling, with a total sample of 80 respondents. Retrieving data using a questionnaire that has been tested for validity and reliability. The analytical method uses multiple linear regression analysis. The results of the study indicate that (1) The marketing mix of services consisting of products, prices, places, promotions, people, physical evidence, and processes simultaneously have a significant effect on consumer decisions. (2) Product variables partially have a significant effect on consumer decisions (3) Price variables partially have no significant effect on consumer decisions. (4) Place variables partially have a significant effect on consumer decisions. (5) Promotional variables partially have a significant effect on consumer decisions. (6) Variables of people partially have a significant effect on consumer decisions. (7) Physical evidence variables partially have a significant effect on consumer decisions. (8) Process variables partially have a significant effect on consumer decisions.
\end{abstract}

Keywords: Service Marketing Mix and Consumer Decisions.

\begin{abstract}
ABSTRAK
Penelitian ini bertujuan untuk mengetahui Pengaruh Bauran Pemasaran Jasa Terhadap Keputusan Konsumen Menggunakan Jasa Pengiriman Barang PT Jalur Nugraha Ekakurir (JNE) Cabang Donggala. Jenis penelitian ini adalah deskriptif kausal. Populasi penelitian ini adalah konsumen yang menggunakan jasa pengiriman barang PT JNE. Teknik penarikan sampel dalam penelitian ini menggunakan accidental sampling, dengan jumlah sampel sebanyak 80 responden. Pengambilan data menggunakan kuesioner yang telah diuji validitas dan reliabilitasnya. Metode analisis menggunakan analisis regresi linear berganda.Hasil penelitian menunjukkan bahwa (1) Bauran pemasaran jasa yang terdiri dari produk, harga, tempat, promosi, orang, bukti fisik, dan proses secara simultan berpengaruh signifikan terhadap keputusan konsumen. (2) Variabel produk secara parsial berpengaruh signifikan terhadap keputusan konsumen (3) Variabel harga secara parsial berpengaruh tidak signifikan terhadap keputusan konsumen. (4) Variabel tempat secara parsial berpengaruh signifikan terhadap keputusan konsumen. (5) Variabel promosi secara parsial berpengaruh signifikan terhadap keputusan konsumen. (6) Variabel orang secara parsial berpengaruh signifikan terhadap keputusan konsumen. (7) Variabel bukti fisik secara parsial berpengaruh signifikan terhadap keputusan konsumen. (8) Variabel proses secara parsial berpengaruh signifikan terhadap keputusan konsumen.
\end{abstract}

Kata Kunci: Bauran Pemasaran Jasa dan Keputusan Konsumen.

\section{PENDAHULUAN}

Disetiap individu atau masyarakat yang melakukan bisnis membutuhkan pengiriman barang yang cepat dan terpercaya untuk memastikan barang yang dikirimkan sampai pada waktunya, dan terjamin tepat. kegiatan pemasaran pasti berhubungan dengan pengiriman barang serta distribusi yaitu menyampaikan barang atau jasa dari pemasok/produsen kepada konsumen/pelanggan untuk memenuhi kebutuhan individu atau manusia. Banyaknya kebutuhan atas pengiriman barang saat ini, banyak 
lahirnya perusahaan jasa pengiriman barang yang terus berkembang dan bersaing untuk merebut pasar saat ini.

Diantaranya PT JNE. jasa pengiriman barang dan pemasaran atau perdagangan memiliki hubungan yang saling mempengaruhi satu sama lain. Berkembangnya perdagangan memicun lahir perusahaan jasa pengiriman atas barang. Dan Jasa pengiriman juga memiliki peran dalam pertumbuhan dan perkembangan perdagangan didalam negeri dan diluar negeri.

JNE juga salah satu perusahaan penyedia jasa logistik terkenal juga terluas di Indonesia JNE berpusat di Jakarta, dan mempunyai pelanggan atau konsumen yang banyak dan cukup di perhitungkan oleh para pesaingnya yang juga bergerak di bidang yang sama pula, JNE melayani pengiriman: paket, dokumen, kendaraan, dan lain-lain. Banyaknya Kebutuhan atas pengiriman barang saat ini, sehingga banyak lahir perusahaan jasa pengiriman. Biaya yang harus di keluarkan oleh setiap konsumen atau pelanggan dalam memperoleh jasa dari PT JNE Cabang Donggala.

Tempat sebagai akses untuk menjangkau lokasi jasa bagi para pelanggan potensial. Hal ini, PT JNE Cabang Donggala berada pada lokasi yang strategis yaitu berada di Jl. Hasanuddin, Tanjung Batu, No.15 Donggala. Dan berada pada pusat perkotaan. Promosi PT JNE Cabang Donggala mempromosikan produk jasa yang mereka miliki melalui media cetak dan media internet seperti produk jasa yang ditawarkan adalah ongkos kirim ekonomi, layanan regular, dan yakin esok sampai. Orang merupakan unsur vital dalam bauran pemasaran. pada PT JNE Cabang Donggala. Dari segi pelayanan yang cepat, keramahan karyawan dan kesopanan karyawan yang diberikan kepada konsumen, hal tersebut sudah pasti membuktikan sumber daya manusia berperan penting dalam hal kenyamanan dan kepuasan yang dirasakan konsumen. Bukti fisik pada PT JNE Cabang Donggala merupakn tampilan bangunan, interior, peralatan, perabotan bahkan sampai keseragaman pakaian karyawan akan tetapi hal tersebut belum memberikan kepuasan tersendiri oleh konsumen itu berarti konsumen perlu merasakan kenyamanan dan ruang tunggu yang layak dan lahan parkir yang luas.

Proses produksi PT JNE Cabang Donggala dengan memberikan pelayanan terbaik kepada pelanggan dengan tingkat kepercayaan dan juga memberikan pelayanan tepat pada waktunya. Seperti halnya barang yang kita kirim, diantar langsung oleh kurir JNE agar langsung diproses pada saat itu juga. Maka dengan adanya bauran pemasaran setiap konsumen akan mudah untuk mengetahui setiap produk, harga, tempat, dan promosi perusahaan yang akan di tawarkan oleh JNE Cabang Donggala secara jelas dan rinci sebelum memilih untuk menggunakan jasanya. Serta dengan adanya bauran pemasaran jasa juga akan dapat menarik perhatian setiap konsumen agar nantinya dapat menerima setiap produk yang ditawarkan oleh JNE kepada konsumen. Fenomena masalah dari JNE Cabang Donggala kebanyakan konsumen jne mengenal jasa pengiriman barang jne ini melalui bisnis online shop seperti shopee, bukalapak dan lain-lain. Berdasarkan rumusan masalah tersebut maka dapat disusun tujuan dari penelitian adalah sebagai berikut: Untuk mengetahui dan menganalisis pengaruh signifikan bauran pemasaran jasa yang terdiri dari produk, harga, tempat, promosi, orang, buki fisik dan proses secara simultan berpengaruh signifikan terhadap keputusan konsumen menggunakan jasa pengiriman barang PT JNE Cabang Donggala.

Untuk mengetahui dan menganalisis pengaruh produk terhadap keputusan konsumen menggunakan jasa pengiriman barang PT JNE Cabang Donggala. Untuk mengetahui dan menganalisis pengaruh harga terhadap keputusan konsumen menggunakan jasa pengiriman barang PT JNE Cabang Donggala. Untuk mengetahui dan menganalisis pengaruh tempat terhadap keputusan konsumen menggunakan jasa pengiriman barang PT JNE Cabang Donggala. Untuk mengetahui dan menganalisis pengaruh promosi terhadap keputusan konsumen menggunakan jasa pengiriman barang PT JNE Cabang Donggala. Untuk mengetahui dan menganalisis pengaruh orang terhadap keputusan konsumen menggunakan jasa pengiriman barang PT JNE Cabang Donggala. Untuk mengetahui dan menganalisis pengaruh bukti fisik terhadap keputusan konsumen menggunakan jasa pengiriman barang PT JNE Cabang Donggala. Untuk mengetahui dan menganalisis pengaruh proses terhadap keputusan konsumen menggunakan jasa pengiriman barang PT JNE Cabang Donggala.

\section{KAJIAN LITERATUR DAN PENGEMBANGAN HIPOTESIS}

\section{Definisi Manajemen Pemasaran}


Menurut Kotler (2009:5), pemasaran adalah sebuah proses kemasyarakatan dimana individu dan kelompok memperoleh apa yang mereka butukan dan inginkan dengan menciptakan, menawarkan, dan secara bebas mempertukarkan produk dan jasa yang bernilai dengan orang lain. Menurut Danang (2015:191), pemasaran adalah fungsi bisnis yang mengidentifiksi kebutuhan dan keinginan konsumen yang harus dipuaskan oleh kegiatan manusia lain, yang menghasilkan alat pemuas kebutuhan, yang berupa barang maupun jasa.

\section{Pengertian Jasa}

Tjiptono (2014:26), jasa atau servis dapat diartikan sebagai "setiap perlakuan atau kelakuan yang dapat ditawar dari suatu pihak kepada pihak lainnya pada hakikatnya bersifat intangible (tidak berwujud fisik) juga tidak menghasilkan kepemilikan atas sesuatu". Menurut Kotler dan Keller (2009:83), jasa atau servis sebagai setiap perlakuan atau kegiatan yang dapat ditawar dari suatu pihak kepada pihak lain, yang pada hakikatnya tidak terwujud dan tidak mengakibatkan kepemilikan apapun atas sesuatu.

\section{Bauran Pemasaran Jasa}

Menurut Kotler dan Keller (2008:4), 7P didefinisikan sebagai berikut:

\section{Product (produk)}

Produk ialah: "a product is a thing that can be offered to a market to satisfy a want or need". Produk adalah segala sesuatu yang dapat ditawarkan kepada pasar untuk memuaskan suatu keinginan atau kebutuhan konsumen. Produk dapat berupa sub kategori yang menjelaskan dua jenis seperti barang dan jasa yang ditujukan kepada target pasar.

\section{Price (harga)}

Harga ialah:"price is the amount of money charged for a product or service". Harga ialah sejumlah uang yang mempunyai nilai tukar dalam memperoleh keuntungan dari memiliki atau menggunakan suatu produk atau jasa. harga merupakan bauran pemasaran yang bersifat fleksibel dimana suatu harga akan stabil dalam jangka waktu tertentu tetapi dalam seketika harga dapat meningkat atau menurun yang terdapat pada pendapatan dari hasil penjualan.

\section{Place (tempat)}

Distribusi ialah:"the various the company undertakes to make the product accessible and available to target customer". Tempat memiliki peranan yang sangat penting dalam membantu perusahaan guna memastikan produknya. Tempat merupakan bagian untuk melakukan kegiatan yang oleh perusahaan untuk membuat produknya mudah diperoleh dan tersedia pada konsumen sasaran. Hal ini dikarenakan tujuan dari tempat adalah menyediakan barang dan jasa yang dibutuhkan dan diinginkan oleh konsumen pada waktu dan tempat yang tepat.

\section{Promotion (promosi)}

Promosi yaitu: "promotion includes all the activities the company undertakes to communicate and promote its product the target market". Promosi ialah semua kegiatan yang dilakukan perusahaan untuk mengkomunikasikan dan mempromosikan produknya kepada pasar sasaran. Promosi dilakukan dengan menggunakan alat-alat promosi yang ada sebagai cara untuk memperkenalkan suatu produk atau jasa.

\section{People (orang)}

Orang ialah: "Proses seleksi, pelatihan, dan motivasi karyawan yang nantinya dapat digunakan sebagai pembedaan perusahaan untuk memenuhi kepuasan pelanggan".

\section{Physical evidence (bukti fisik)}

Bukti fisik ialah: "bukti yang dimiliki oleh penyedia jasa yang ditujukan kepada konsumen sebagai usulan nilai tambah konsumen. Bukti fisik adalah wujud nyata yang ditawarkan kepada pelanggan ataupun calon pelanggan". 


\section{Process (proses)}

Proses ialah: "Semua prosedur aktual, mekanisme dan aliran aktivitas dengan jasa disampaikan yang merupakan sistem penyajian atas operasi jasa".

\section{METODE PENELITIAN}

Jenis penelitian yang dilakukan oleh peneliti yaitu penelitian deskriptif kausal dan pendekatan survei. Lokasi yang dijadikan obyek penelitian adalah Perusahaan PT JNE Cabang Donggala, yang terletak di Jl. Hasanuddin No. 15 Tanjung Batu, Kecamatan Banawa, Kabupaten Donggala. terletak di tengah kota Donggala sehingga akses untuk menjangkaunya lebih mudah. Objek penelitian adalah pengaruh bauran pemasaran jasa terhadap keputusan konsumen. Subjek dari penelitian ini adalah konsumen yang menggunakan jasa pengiriman barang PT JNE Cabang Donggala. Jenis Data Jenis data yang digunakan dalam penelitian ini meliputi dua jenis data yaitu: Data kuantitatif dan kualitatif. Sumber data yang dalam penelitian ini dua jenis data yaitu data primer dan data sekunder

Populasi dari penelitian ini adalah konsumen atau pelanggan yang menggunakan jasa pengiriman barang PT JNE Cabang Donggala. Adapun jumlah populasi dalam penelitian ini tidak diketahui secara pasti karena setiap konsumen yang mengirim merupakan rahasia bagi PT JNE Cabang Donggala. Karena populasi tidak diketahui maka teknik penarikan sampel yang digunakan dalam penelitian ini adalah teknik insedental sampling, Menurut Sugiyono (2014:122) Berdasarkan teori tersebut maka perhitungan sampel dalam penelitian ini diuraikan sebagai berikut: 10 x $8=80$ sampel". Jadi jumlah sampel yang digunakan dalam penelitian ini sebanyak 80 orang sampel

\section{Uji Regresi Linear Berganda}

Untuk mengetahui seberapa besar pengaruh variable bebas yaitu: Produk (X1), Harga (X2), Tempat (X3), Promosi (X4), Orang (X5), Bukti FIsik (X6), Proses (X7).

Model umum bentuk persamaan alat analisis statistik parametrik regresi linear berganda dapat digambarkan sebagai (Sugiyono 2014:298).

$$
\mathbf{Y}=\mathbf{a}+\mathbf{b}_{1} \mathbf{X}_{1}+\mathbf{b}_{2} \mathbf{X}_{2}+\mathbf{b}_{3} \mathbf{X}_{3}+\ldots \mathbf{b}_{7} \mathbf{X}_{7+} \mathbf{e}
$$

Di mana:

$\begin{aligned} \mathrm{Y} & =\text { Variabel Dependen } \\ \mathrm{a} & =\text { Konstanta (intercept) } \\ \mathrm{b} & =\text { Koefisien Regresi } \\ \mathrm{X} 1 & =\text { Produk } \\ \mathrm{X} 2 & =\text { Harga } \\ \mathrm{X} 3 & =\text { Tempat } \\ \mathrm{X} 4 & =\text { Promosi } \\ \mathrm{X} 5 & =\text { Orang } \\ \mathrm{X} 6 & =\text { Bukti Fisik } \\ \mathrm{X} 7 & =\text { Proses } \\ \mathrm{e} & =\text { Error }\end{aligned}$




\section{HASIL DAN PEMBAHASAN}

Hasil Uji Regresi Linear Berganda

Tabel 1

Rekapitulasi Hasil Uji Regresi Linear Berganda

\begin{tabular}{|c|c|c|c|c|c|}
\hline \multicolumn{6}{|c|}{ Dependen Variabel Y = Keputusan Konsumen } \\
\hline \multirow[t]{2}{*}{ Variabel Independen } & \multicolumn{2}{|c|}{$\begin{array}{l}\text { Unstandardized } \\
\text { Coefficients }\end{array}$} & \multirow{2}{*}{$\begin{array}{c}\begin{array}{c}\text { Standardized } \\
\text { Coefficients }\end{array} \\
\text { Beta }\end{array}$} & \multirow[t]{2}{*}{$\mathbf{t}$} & \multirow[t]{2}{*}{ Sig } \\
\hline & B & $\begin{array}{c}\text { Standar } \\
\text { Error }\end{array}$ & & & \\
\hline $\mathrm{C}=$ Constanta & .151 & .126 & & 1.193 & .237 \\
\hline Produk $\left(\mathrm{X}_{1}\right)$ & .373 & .049 & .465 & 7.727 & .000 \\
\hline Harga $\left(\mathrm{X}_{2}\right)$ & .027 & .036 & .024 & 746 & .458 \\
\hline Tempat $\left(\mathrm{X}_{3}\right)$ & .116 & .031 & .132 & 3.778 & .000 \\
\hline Promosi $\left(\mathrm{X}_{4}\right)$ & .119 & .036 & .133 & 3.297 & .002 \\
\hline Orang $\left(X_{5}\right)$ & .287 & .047 & .325 & 6.095 & .000 \\
\hline Bukti Fisik $\left(\mathrm{X}_{6}\right)$ & .352 & .050 & .333 & 7.017 & .000 \\
\hline Proses $\left(\mathrm{X}_{7}\right)$ & .218 & .049 & .210 & 4.427 & .000 \\
\hline $\begin{array}{ll}\text { Multiple } R & =.981 \\
\text { R Square }\left(R^{2}\right) & =.962\end{array}$ & & $\begin{array}{l}\text { Sig.F } \\
\text { F }\end{array}$ & $\begin{array}{l}=.000 \\
=258.041\end{array}$ & & \\
\hline
\end{tabular}

Sumber: Data Primer, Diolah Kembali

Dari hasil uji regresi yang tertera pada Tabel 1 di atas, dapat diketahui bahwa persamaan regresinya adalah:

$$
Y=0.151+0,373 X 1+0,027 X 2+0,116 \times 3+0,119 X 4+0,287 X 5+0,352 \times 6+0,218 \times 7
$$
berikut:

Berdasarkan persamaan regresi linear berganda di atas, dapat diinterpretasikan sebagai

1) Nilai Konstanta $Y$ (Keputusan Konsumen) sebesar 0.151. Artinya, jika nilai variabel produk $\left(\mathrm{X}_{1}\right)$, harga $\left(\mathrm{X}_{2}\right)$, tempat $\left(\mathrm{X}_{3}\right)$, promosi $\left(\mathrm{X}_{4}\right)$, orang $\left(\mathrm{X}_{5}\right)$, bukti fisik $\left(\mathrm{X}_{6}\right)$ dan proses $\left(\mathrm{X}_{7}\right)$ bernilai 0, maka keputusan konsumen $(\mathrm{Y})$ sebesar 0.151 .

2) Koefisien regresi variabel produk $\left(X_{1}\right)$ sebesar 0,373. Artinya, jika kualitas produk dipersepsikan meningkat maka keputusan konsumen menggunakan jasa meningkat.

3) Koefisien regresi variabel harga $\left(X_{2}\right)$ sebesar 0,027. Artinya, jika kualitas harga dipersepsikan meningkat maka keputusan konsumen menggunakan jasa meningkat.

4) Koefisien regresi variabel tempat $\left(\mathrm{X}_{3}\right)$ sebesar 0,116. Artinya, jika kualitas tempat dipersepsikan meningkat maka keputusan konsumen menggunakan jasa meningkat.

5) Koefisien regresi variabel promosi $\left(\mathrm{X}_{4}\right)$ sebesar 0,119. Artinya, jika kualitas promosi dipersepsikan meningkat maka keputusan konsumen menggunakan jasa meningkat.

6) Koefisien regresi variabel orang $\left(X_{5}\right)$ sebesar 0,287 . Artinya, jika kualitas orang dipersepsikan meningkat maka keputusan konsumen menggunakan jasa meningkat.

7) Koefisien regresi variabel bukti fisik $\left(\mathrm{X}_{6}\right)$ sebesar 0,352. Artinya, jika kualitas bukti fisik dipersepsikan meningkat maka keputusan konsumen menggunakan jasa meningkat.

8) Koefisien regresi variabel proses $\left(\mathrm{X}_{7}\right)$ sebesar 0,218. Artinya, jika kualitas promosi dipersepsikan meningkat maka keputusan konsumen menggunakan jasa meningkat.

9) Hasil perhitungan nilai koefisien determinasi yang diperoleh sebesar 0,962. Hal ini berarti 96,2\% keputusan konsumen dapat dijelaskan oleh variabel bauran pemasaran jasa, sedangkan sisanya yaitu 3,8\% keputusan konsumen dipengaruhi oleh variabel-variabel lainnya yang tidak diteliti dalam penelitian ini.

\section{Pengujian Hipotesis Pertama (Uji Serempak / Uji F)}


Berdasarkan Tabel 5.18 hasil pengujian dengan SPSS angka signifikansi sebesar 0,000. Angka $0,000<0,05$ oleh karena itu, hipotesis diterima. Hal ini berarti variabel $\mathrm{X}$ (bauran pemasaran) berpengaruh terhadap variabel Y (keputusan konsumen).

\section{Pengujian Hipotesis Ke Dua $\left(\mathrm{X}_{1}\right)$}

Berdasarkan Tabel 5.18 hasil pengujian dengan SPSS angka signifikansi sebesar 0,000. Angka $0,000<0,05$ oleh karena itu, hipotesis diterima. Hal ini berarti variabel $\mathrm{X}_{1}$ (produk) berpengaruh terhadap variabel Y (keputusan konsumen).

Pengujian Hipotesis Ke Tiga $\left(\mathrm{X}_{2}\right)$

Berdasarkan Tabel 5.18 hasil pengujian dengan SPSS angka signifikansi sebesar 0,458. Angka 0,458 > 0,05 oleh karena itu, hipotesis tidak diterima. Hal ini berarti variabel $\mathrm{X}_{2}$ (harga) tidak berpengaruh terhadap variabel Y (keputusan konsumen).

\section{Pengujian Hipotesis Ke Empat $\left(\mathrm{X}_{3}\right)$}

Berdasarkan Tabel 5.18 hasil pengujian dengan SPSS angka signifikansi sebesar 0,000. Angka $0,000<0,05$ oleh karena itu, hipotesis diterima. Hal ini berarti variabel $\mathrm{X}_{3}$ (tempat) berpengaruh terhadap variabel Y (keputusan konsumen).

\section{Pengujian Hipotesis Ke Lima $\left(\mathbf{X}_{4}\right)$}

Berdasarkan Tabel 5.18 hasil pengujian dengan SPSS angka signifikansi sebesar 0,002. Angka $0,002<0,05$ oleh karena itu, hipotesis diterima. Hal ini berarti variabel $\mathrm{X}_{4}$ (promosi) berpengaruh terhadap variabel Y (keputusan konsumen).

\section{Pengujian Hipotesis Ke Enam ( $\left.\mathbf{X}_{5}\right)$}

Berdasarkan Tabel 5.18 hasil pengujian dengan SPSS angka signifikansi sebesar 0,000. Angka $0,000<0,05$ oleh karena itu, hipotesis diterima. Hal ini berarti variabel $\mathrm{X}_{5}$ (orang) berpengaruh terhadap variabel Y (keputusan konsumen).

\section{Pengujian Hipotesis Ke Tujuh (X6)}

Berdasarkan Tabel 5.18 hasil pengujian dengan SPSS angka signifikansi sebesar 0,000. Angka $0,000<0,05$ oleh karena itu, hipotesis diterima. Hal ini berarti variabel $\mathrm{X}_{6}$ (bukti fisik) berpengaruh terhadap variabel Y (keputusan konsumen).

\section{Pengujian Hipotesis Ke Delapan $\left(\mathrm{X}_{7}\right)$}

Berdasarkan Tabel 5.18 hasil pengujian dengan SPSS angka signifikansi sebesar 0,000. Angka $0,000<0,05$ oleh karena itu, hipotesis diterima. Hal ini berarti variabel $\mathrm{X}_{7}$ (proses) berpengaruh terhadap variabel Y (keputusan konsumen).

Pembahasan Atas Hasil Analisis

Pengaruh Produk $\left(\mathbf{X}_{1}\right)$ Terhadap Keputusan Konsumen Menggunakan Jasa Pengiriman Barang pada PT JNE Cabang Donggala.

Hasil penelitian menunjukkan bahwa variabel produk berpengaruh signifikan terhadap keputusan konsumen. Produk yang terdiri atas indikator beragamnya fitur produk dan keunggulan jasa yang ditawarkan lebih dari pesaing dapat mempengaruhi konsumen dalam melakukan keputusan menggunakan jasa pengiriman barang pada PT JNE Cabang Donggala. Hal ini dikarenakan produk jasa dari PT JNE yaitu jasa pengiriman YES, REG dan OKE merupakan produk yang sudah akrab bagi masyarakat sebagai konsumen.

Pengaruh Harga $\left(\mathbf{X}_{2}\right)$ Terhadap Keputusan Konsumen Menggunakan Jasa Pengiriman Barang pada PT JNE Cabang Donggala.

Hasil penelitian menunjukkan bahwa variabel harga tidak berpengaruh signifikan terhadap keputusan konsumen. Harga dengan nilai indikator tertinggi yaitu harga yang ditawarkan sesuai dengan kualitas tidak dapat mempengaruhi konsumen dalam melakukan keputusan menggunakan jasa pengiriman barang pada PT JNE Cabang Donggala. Hal ini dikarenakan konsumen merasa sering kecewa dengan jasa pengiriman maupun layanan pengantaran yang terkadang mengalami keterlambatan khususnya pada jasa pengiriman REG dan OKE. Selain itu, Penetapan harga yang dilakukan PT JNE Cabang Donggala tidak dapat mempengaruhi keputusan menggunakan jasa pada PT JNE Cabang Donggala disebabkan harga yang ditetapkan perusahaan memakai minimum jumlah berat barang. Penetapan harga yang dilakukan PT JNE Cabang Donggala tidak sesuai dengan jumlah 
pengiriman yang dimana konsumen tidak bisa menetapkan jumlah kiriman yang akan mereka kirimkan.

Pengaruh Tempat $\left(\mathrm{X}_{3}\right)$ Terhadap Keputusan Konsumen Menggunakan Jasa Pengiriman Barang pada PT JNE Cabang Donggala.

Hasil penelitian menunjukkan bahwa variabel tempat/lokasi berpengaruh signifikan terhadap keputusan konsumen. Tempat dengan nilai indikator tertinggi yaitu lokasi strategis dipusat keramaian dapat mempengaruhi konsumen dalam melakukan keputusan menggunakan jasa pengiriman barang pada PT JNE Cabang Donggala. Hal ini dikarenakan lokasi PT JNE Cabang Donggala berada dekat dengan pusat kota atau pusat keramaian, akses transportasi mudah, dan dengan kondisi lingkungan yang nyaman sehingga dapat mempengaruhi keputusan konsumen untuk menggunakan jasa pengiriman di PT JNE Cabang Donggala. Hal ini juga dapat membuktikan bahwa konsumen dalam memutuskan untuk menggunakan jasa pengiriman dipengaruhi oleh tempat yang baik, bukan hanya ketersediaan produk yang dibutuhkan saja. Hasil penelitian mendukung penelitian Farna (2009), Lita (2010), dan Margaret, Siagian, Brastoro (2010) yang menyatakan bahwa lokasi pelayanan jasa yang digunakan dalam memasok jasa kepada pelanggan yang dituju merupakan keputusan kunci. Tempat juga penting sebagai lingkungan dimana dan bagaimana jasa akan di serahkan, sebagian dari nilai dan manfaat dari jasa.

Pengaruh Promosi $\left(\mathbf{X}_{4}\right)$ Terhadap Keputusan Konsumen Menggunakan Jasa Pengiriman Barang pada PT JNE Cabang Donggala.

Hasil penelitian menunjukkan bahwa variabel promosi berpengaruh signifikan terhadap keputusan konsumen. Promosi dengan nilai indikator tertinggi yaitu iklan/informasi pada internet (situs resmi) dapat mempengaruhi konsumen dalam melakukan keputusan menggunakan jasa pengiriman barang pada PT JNE Cabang Donggala. Hal ini dikarenakan situs www.jne.co.id menyediakan berbagai informasi yang dapat dilihat oleh konsumen jika akan mencari tahu tentang perusahaan, produk dan layanan yang ditawarkan. Dalam menjalankan usaha, kegiatan promosi merupakan sistem pemasaran yang sangat berpengaruh bagi perusahaan, dimana dapat diperoleh suatu pengertian bahwa promosi berperan sebagai strategi pemasaran yang memiliki kelebihan dalam peningkatan faktor yang terpenting ialah peningkatan volume penjualan.

Pengaruh Orang $\left(\mathbf{X}_{5}\right)$ Terhadap Keputusan Konsumen Menggunakan Jasa Pengiriman Barang pada PT JNE Cabang Donggala.

Hasil penelitian menunjukkan bahwa variabel orang berpengaruh signifikan terhadap keputusan konsumen. Orang dengan nilai indikator tertinggi yaitu karyawan ramah terhadap konsumen dapat mempengaruhi konsumen dalam melakukan keputusan menggunakan jasa pengiriman barang pada PT JNE Cabang Donggala. Dari hasil pengamatan peneliti pelayanan di PT JNE Cabang Donggala memang sangat baik diberikan oleh karyawan. Pelayanan yang ramah dalam melakukan hubungan, menyampaikan kondisi barang, komunikasian yang baik dalam memberikan penjelasakan kepada konsumen memberikan pengaruh positif. Keramahan petugas dan cara petugas berkomunikasi pada saat memberikan pelayanan maka konsumen akan terpuaskan dan akan tetap memakai jasa pelayanan PT JNE Cabang Donggala ini untuk waktu-waktu yang akan datang. Hal ini didukung oleh pendapat Alma (2003), yang menyatakan bahwa orang (People) berarti orang yang melayani ataupun merencanakan pelayanan terhadap para konsumen. Karena sebagian besar jasa dilayani oleh orang, maka orang tersebut perlu diseleksi, dilatih, dimotivasi sehingga memberikan kepuasan terhadap konsumen.

Pengaruh Bukti Fisik $\left(\mathbf{X}_{6}\right)$ Terhadap Keputusan Konsumen Menggunakan Jasa Pengiriman Barang pada PT JNE Cabang Donggala.

Hasil penelitian menunjukkan bahwa bukti fisik berpengaruh signifikan terhadap keputusan konsumen. Bukti fisik dengan nilai indikator tertinggi yaitu kerapian ruangan dapat mempengaruhi konsumen dalam melakukan keputusan menggunakan jasa pengiriman barang pada PT JNE Cabang Donggala. Ruangan yang rapi membuat konsumen merasa nyaman berada dalam ruangan bahkan betah untuk berlama-lama. Penelitian ini didukung oleh pernyataan dari Oesman (2010:31) yang mengemukakan bahwa bukti fisik yang disediakan menunjukan kualitas jasa perusahaan sehingga perusahaan perlu mengelola bukti fisik ini dengan hati-hati karena dapat mempengaruhi kesan konsumen terhadap perusahaan. 


\section{Pengaruh Proses $\left(\mathbf{X}_{7}\right)$ Terhadap Keputusan Konsumen Menggunakan Jasa Pengiriman Barang pada PT JNE Cabang Donggala.}

Hasil penelitian menunjukkan bahwa proses berpengaruh signifikan terhadap keputusan konsumen. Proses dengan nilai indikator tertinggi yaitu proses pengiriman barang yang sesuai jadwal dapat mempengaruhi konsumen dalam melakukan keputusan menggunakan jasa pengiriman barang pada PT JNE Cabang Donggala. Proses (Process) adalah semua prosedur aktual, mekanisme, dan aliran aktivitas yang digunakan untuk menyampaikan jasa. Elemen proses ini memiliki arti sesuatu dalam menyampaikan jasa. Proses dalam jasa merupakan faktor utama dalam bauran pemasaran jasa seperti pelanggan jasa akan senang merasakan sistem penyerahan jasa sebagai bagian jasa itu sendiri. Proses pengiriman yang sesuai jadwal akan membuat konsumen merasa terlayani dengan baik.

\section{KESIMPULAN DAN SARAN}

\section{Kesimpulan}

Berdasarkan hasil dari penelitian dan pembahasan, maka dapat ditarik kesimpulan sebagai berikut :

1. Bauran pemasaran jasa yang terdiri dari produk, harga, tempat, promosi, orang, bukti fisik, dan proses secara simultan berpengaruh signifikan terhadap keputusan konsumen menggunakan jasa pengiriman barang pada PT JNE Cabang Donggala.

2. Variabel produk secara parsial berpengaruh signifikan terhadap keputusan konsumen menggunakan jasa pengiriman barang pada PT JNE Cabang Donggala.

3. Variabel harga secara parsial tidak berpengaruh signifikan terhadap keputusan konsumen menggunakan jasa pengiriman barang pada PT JNE Cabang Donggala.

4. Variabel tempat secara parsial berpengaruh signifikan terhadap keputusan konsumen menggunakan jasa pengiriman barang pada PT JNE Cabang Donggala.

5. Variabel promosi secara parsial berpengaruh signifikan terhadap keputusan konsumen menggunakan jasa pengiriman barang pada PT JNE Cabang Donggala.

6. Variabel orang secara parsial berpengaruh signifikan terhadap keputusan konsumen menggunakan jasa pengiriman barang pada PT JNE Cabang Donggala.

7. Variabel bukti fisik secara parsial berpengaruh signifikan terhadap keputusan konsumen menggunakan jasa pengiriman barang pada PT JNE Cabang Donggala.

8. Variabel proses secara parsial berpengaruh signifikan terhadap keputusan konsumen menggunakan jasa pengiriman barang pada PT JNE Cabang Donggala.

\section{Saran}

Berdasarkan hasil dari penelitian, pembahasan dan kesimpulan yang diperoleh, maka saran yang dapat diberikan sebagai berikut :

1. Bagi Perusahaan

a) Hasil tanggapan responden pada variabel produk mengenai indikator manfaat produk jasa yang ditawarkan merupakan indikator dengan nilai rata-rata terendah. Oleh karena itu, disarankan kepada PT JNE Cabang Donggala sebaiknya harus memperhatikan feedback atau manfaat yang didapatkan oleh konsumen terhadap apa yang perusahaan tawarkan sehingg konsumen akan merasa puas.

b) Hasil tanggapan responden pada variabel harga mengenai indikator harga bervariatif merupakan indikator dengan nilai rata-rata terendah. Oleh karena itu, disarankan kepada pihak PT JNE Cabang Donggala untuk tetap mempertahankan harga yang ditentukan tetapi dengan kualitas layanan yang baik pula.

c) Hasil tanggapan responden pada variabel tempat mengenai indikator lokasi strategis di pusat kota merupakan indikator dengan nilai rata-rata terendah. Oleh karena itu, agar supaya minat konsumen untuk menggunakan jas PT JNE Cabang Donggala besar, maka diperlukan perhatian khusus dari pihak manajemen dalam menentukan lokasi kantor cabang.

d) Hasil tanggapan responden pada variabel promosi mengenai indikator penyampaian iklan dan pengenalan produk jelas merupakan indikator dengan nilai rata-rata terendah. Oleh karena itu, disarankan kepada PT JNE Cabang Donggala untuk juga beriklan khusus untuk masyarakat Donggala. 
e) Hasil tanggapan responden pada variabel orang mengenai indikator lokasi pelayanan yang diberikan karyawan cepat merupakan indikator dengan nilai rata-rata terendah. Hal ini menunjukan bahwa perlunya PT JNE Cabang Donggala, melatih lagi SDM yang mereka miliki.

f) Hasil tanggapan responden pada variabel bukti fisik mengenai indikator tersedianya lahan parkir luas merupakan indikator dengan nilai rata-rata terendah. Maka dari itu perlu adanya pembangunan lahan parkiran bagi konsumen PT JNE Cabang Donggala.

g) Hasil tanggapan responden pada variabel proses mengenai indikator proses pembayaran cepat merupakan indikator dengan nilai rata-rata terendah. Hal ini berarti kurangnya perhatian karyawan terhadap konsumen. Maka dari itu perlu adanya pelatihan SDM bagi PT JNE dalam meningkatkan mutu layanan perusahaan.

2. Bagi Peneliti Selanjutnya

Bagi peneliti selanjutnya, dianjurkan untuk menganalisis lebih dalam dan lebih spesifik dan memasukan variabel lainyang tidak termasuk dalam model penelitian ini. Untuk variabel yang tidak berpengaruh agar lebih dianalisis sehingga hasil yang didapatkan juga lebih maksimal.

\section{REFERENSI}

Gozali, Imam. 2007. Aplikasi Analisis Multivariate Dengan Program SPSS, Semarang: Badan Penerbit Universitas di Ponegoro.

Kotler, Philip dan Kevin Lane Keller, 2009. Manajemen Pemasaran Edisi ketigabelas, jilid I, Jakarta: Penerbit Erlangga.

Kotler, Philip, dan Gary Armstrong, 2008, Prinsip - Prinsip Pemasaran Edisi Keduabelas, jilid 2, Jakarta: Penerbit Erlangga.

Kuncoro, Mudrajat, 2009. Metode Riset untuk Bisnis dan Ekonomi. Edisi Ketiga, Erlangga, Jakarta.

Kurniawan, Albert. 2014 Metode Riset Untuk Ekonomi dan Bisnis. Alfabeta. Bandung.

Sunyoto, Danang, 2015. Perilaku Konsumen Dan Manajemen Pemasaran : Cetakan pertama, penerbit PT. Buku Seru.

Sugiyono, 2014, Metode Penelitian Bisnis (Pendekatan Kuantitatif, Kualitatif dan R\&D). Bandung: CV. Alfabeta.

Sugiyono, 2013. Metode Penelitian Bisnis (Pendekatan Kuantitatif, Kualitatif, dan R\&D). Penerbit CV Alfabeta, Bandung.

Tjiptono . Fandy.2014. Pemasaran Jasa Prinsip , penerapan dan Penelitian . yongyakarta. Penerbit Andi.

\section{Sumber Lain :}

www.Jne.co.id

www.Cektarif.com 